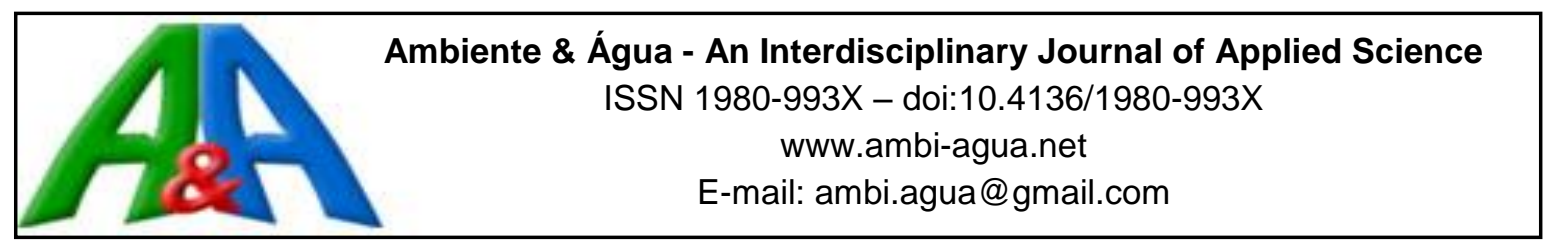

\title{
Use of zeolite synthesized from coal ashl from Santa Catarina for removal of iron, manganese and methylene blue dye in water
}

\author{
ARTICLES doi:10.4136/ambi-agua.2224
}

Received: 23 Dec. 2017; Accepted: 04 May 2018

\author{
Jair Juarez João ${ }^{1 *}$; Walter Satiro Júnior² ${ }^{2}$ José Luiz Vieira² \\ ${ }^{1}$ Universidade do Sul de Santa Catarina (UNISUL), Tubarão, SC, Brasil \\ Mestrado em Ciências Ambientais. E-mail: jair.joao@unisul.br \\ ${ }^{2}$ Universidade do Sul de Santa Catarina (UNISUL), Tubarão, SC, Brasil \\ Departamento de Engenharia Química (EQM). E-mail: walter@ projelab.eco.br, \\ jlvieira1994@uol.com.br \\ *Corresponding author
}

\begin{abstract}
The fly ash of coal, generated in a thermoelectric plant, was used to synthesize zeolite by hydrothermal treatment with a sodium hydroxide solution. The zeolite synthesized was used as an adsorbent of metals ( $\mathrm{Fe}$ and $\mathrm{Mn}$ ) and of the methylene blue dye in water. The characterization of the zeolite showed that silicon oxide is the main compound in its composition, followed by aluminum, iron, sodium and calcium, which together correspond to more than $86 \%$ of its composition. These were used to investigate the kinetic parameters of adsorption and the isotherm of the metals and the methylene blue dye in aqueous solutions. Three kinetic models, pseudo-first order, pseudo-second order and intraparticle diffusion were used to predict adsorption rate constants. The adsorption kinetics of the dye and metals followed the pseudosecond order kinetics and reached equilibrium in 15 minutes with a $99 \%$ removal rate for metals, independently of the $\mathrm{pH}$. The values of the diffusion constants $\left(\mathrm{K}_{2}\right)$ for iron in $\mathrm{pH} 5,7$ and 8 were $1.3158 ; 1.3881 \mathrm{e} 0.6053 \mathrm{mg} \cdot \mathrm{g}^{-1} \cdot \mathrm{min}^{-1}$ and for manganese $1.2511 ; 1.5239$ and $1.4336 \mathrm{mg} \cdot \mathrm{g}^{-1} \cdot \mathrm{min}^{-1}$, respectively. For methylene blue, the removal rate was $90 \%$ and the constant $\left(\mathrm{K}_{2}\right)$ value was $0.5437 \mathrm{mg} \cdot \mathrm{g}^{-1} \cdot \mathrm{min}^{-1}$. The studies showed the existence of different stages in the adsorption of the metals and the methylene blue dye in zeolite.
\end{abstract}

Keywords: coal ashes, water purification, zeolite.

\section{Uso de zeólita sintetizada a partir de cinzas de carvão de Santa Catarina para remoção de ferro, manganês e o corante azul de metileno em água}

\section{RESUMO}

As cinzas volantes de carvão, geradas em uma usina termelétrica, foram utilizadas para sintetizar zeólita por tratamento hidrotérmico com solução de hidróxido de sódio. A zeólita sintetizada foi utilizada como adsorvente de metais (Fe e Mn) e do corante azul de metileno em água. A caracterização da zeólita, mostrou que o óxido de silício é o principal composto na sua composição, seguido pelo alumínio, ferro, sódio e cálcio, que juntos correspondem a mais de $86 \%$ da sua composição. Estas foram utilizadas para investigar os parâmetros cinéticos de 
adsorção e a isoterma dos metais e do corante azul de metileno em soluções aquosas. Três modelos cinéticos, pseudo-primeira ordem, pseudo-segunda ordem e difusão intrapartícula foram utilizados para prever as constantes da taxa de adsorção. A cinética de adsorção do corante e dos metais seguiram a cinética de pseudo-segundo ordem e, atingiram o equilíbrio em 15 minutos com uma taxa de remoção $99 \%$ para os metais, independentemente do $\mathrm{pH}$. Os valores das constantes de difusão (K2) para o ferro em pH 5, 7 e 8 foram 1,3158; 1,3881 e $0,6053 \mathrm{mg} \cdot \mathrm{g}^{-1} \cdot \mathrm{min}^{-1}$ e para o manganês 1,$2511 ; 1,5239$ e $1,4336 \mathrm{mg} \cdot \mathrm{g}^{-1} \cdot \mathrm{min}^{-1}$, respectivamente. Para o azul de metileno a taxa de remoção foi de $90 \%$ e o valor da constante (K2) foi de $0,5437 \mathrm{mg} \cdot \mathrm{g}^{-1} \cdot \mathrm{min}^{-1}$. Os estudos também mostraram a existência de diferentes estágios na adsorção dos metais e do corante azul de metileno em zeólita.

Palavras-chave: cinzas de carvão, purificação de água, zeólita.

\section{INTRODUCTION}

Mineral coal is one of the more abundant and widely distributed fossil fuels in the world, with proven global reserves of almost 1000 billion tons. It is found in subsoil deposits and extracted by mining. Coal feeds most electricity production in several countries, like South Africa (93\%), Poland (92\%), China (79\%), India (69\%) and the United States (49\%) (Bukhari et al., 2014).

In Brazil, the energy matrix results from several sources, and one of them is from mineral coal burning, which generates about 1.3 to $1.5 \%$ of the electric energy used in the country. This electricity generation through thermal electrical plants produces about 3 million tons of ashes yearly, which were composed of 65 to $85 \%$ fly ash and 15 to $35 \%$ heavy ash (Cardoso et al., 2015a). Around the world, about 500 million tons of fly ash and 100 million of heavy ash are generated by year (Cunico et al., 2009).

Ash disposal directly on the environment maximizes negative environmental impact (Yao et al., 2015). The main effort to minimize the impacts of the disposal of these residues in the environment must be a search for enlarging potentialities for their use (Itskos et al., 2015).

Only 30 to $35 \%$ of fly ash are used to produce pozzolanic cement, fertilizers and in paving (Hemalatha and Ramaswamy, 2017), while the heavy ash still does not have much commercial application. There are several studies to use ashes in other fields, like metal removal of industrial interest (Tang and Steenari, 2015), ceramic application (Luoa et al., 2017; Zhu et al., 2016), geopolymer production (Mehta and Siddique, 2017; Dassekpo et al., 2017) and in the synthesis of several zeolites (Ojumu et al., 2016; Cardoso et al., 2015b).

Mineral coal fly ashes are constituted basically of silica and alumina, and it is possible to change them into zeolite material after hydrothermal treatment in an alkaline medium (Lee et al., 2017; Fukasawa et al., 2017).

According to Ayele et al. (2016), zeolites are crystalline microporous materials, and during the second half of the 20th century and the early decades of the 21 st century, they have been consolidated as important catalysts in processes in the oil refining, chemical and petrochemical industries (Rehan et al., 2017), as well as in environmental control (Nekhunguni et al., 2017; Wan et al., 2017).

Fly ash is an ideal precursor to zeolite production due to its composite similarity with volcanic materials, $\mathrm{SiO}_{2}$ and $\mathrm{Al}_{2} \mathrm{O}_{3}$. Zeolite material is still characterized by high capacity for cation exchange and good adsorption, which enables several industrial uses in water and liquid effluent treatment. Therefore, they are an alternative to reduce environmental impacts due to their disposition in the environment (Visa, 2016). This broad spectrum of applications is related to the physical and chemical properties of these materials, which can be controlled during their preparation for a specific application (Abdelrasoul et al., 2017). 
Activated coal has been widely used to remove contaminants from residual water due to its large surface area and excellent capacity for adsorption of these composites; however, the high cost has limited its usage (Simate et al., 2016; Mor et al., 2017). This fact aroused interest to develop other low cost products using the residue generated in coal thermal electrical plants (ashes) as raw material for the production of adsorbent (Attari et al., 2017). It is important to mention that rapid industrialization and urbanization has led to the contamination of sediments and water with metals and organic contaminants that created a pervasive problem worldwide. Major sources of contamination include agricultural, human and industrial activities, spills, drainage of mines and accidents.

Water and sediments containing these contaminants act as secondary sources of contamination, posing significant direct and indirect environmental risks through bioaccumulation in aquatic organisms and incorporation into aquatic food webs that may lead to human exposure (Knox, 2016). In this way, the quality of water can easily degraded by contaminants from anthropogenic activities and natural phenomena such as erosion and volcanic activity. Among common contaminants, metals and metalloids may pose significant risks to human life, living organisms and natural ecosystems because of their toxicity, persistence, and accumulation potential (Calugaru et al., 2018).

It is important that wastewater that contains metals, especially iron $(\mathrm{Fe})$ and manganese $(\mathrm{Mn})$, be treated properly for reuse applications or disposed of at the appropriate levels so as not to have an impact on public health. Iron, although not a toxic element, presents several problems for the public water supply. Besides conferring color and flavor to the water, it also causes the development of deposits in pipes and iron-bacteria, causing the biological contamination of the water. Unlike iron, manganese when inhaled may cause irritation, respiratory tract infection, and pneumonitis. Therefore, developing simple and cheap new technologies that enable the reduction of the pollution charge from water and industrial effluents (residual water) are strategic studies to ensure the continuation of these activities in industrial regions. Further, throwing contaminated wastewater in water chains reduces the photosynthetic activity and affects the natural balance of biota (Nimick et al., 2011).

Within this context, the main objective of the present work was to synthesize zeolite from coal ash and use it as an adsorbent in residual water treatment to remove metals ( $\mathrm{Fe}$ and $\mathrm{Mn}$ ) and methylene blue dye.

\section{MATERIALS AND METHODS}

\subsection{Materials and reagents}

The methylene blue dye and the sodium hydroxide $(\mathrm{NaOH})$ used in this study were purchased with Vetec, purity $\geq 99 \%$. All other reagents (analytical-reagent grade) were purchased from Merck. The iron chloride tetrahydrate $\left(\mathrm{FeCl}_{2} \cdot 4 \mathrm{H}_{2} \mathrm{O}\right)$ and manganese chloride tetrahydrate $\left(\mathrm{MnCl}_{2} .4 \mathrm{H}_{2} \mathrm{O}\right)$ were quantitatively dissolved in deionized water (Millipore Milli$\mathrm{Q}$ system) for preparing solutions containing ions $\mathrm{Mn}^{+2}$ and $\mathrm{Fe}^{+2}$.

\subsection{Synthesis of zeolite}

Synthetic zeolite was prepared from fly ashes retained in the bag filter, collected in the Usina Termelétrica Carbonifera Jorge Lacerda, which belongs to Tractebel Energia/ENGIE, located in Capivari de Baixo town, Santa Catarina state, Brazil.

Zeolite synthesis was performed in two types of reactor, semi-open and closed. A closed system reactor produced zeolite with morphological characteristics and appropriate chemical purity, which agrees a description in the literature (Bruno, 2008).

To perform the reaction, $30 \mathrm{~g}$ of ash were placed inside the reactor, and the $\mathrm{NaOH}$ ( $\left.3.5 \mathrm{~mol} . \mathrm{L}^{-1}\right)$ at $100^{\circ} \mathrm{C}$ mass variates $(60$ to $300 \mathrm{~g}$ ) for 24 hours. After finishing the reaction, the 
suspension was filtered and the residue was washed repeatedly with deionized water until achieving $\mathrm{pH} \sim 10$. The residue was washed in a stove at $50^{\circ} \mathrm{C}$ for $12 \mathrm{~h}$. It is important highlight that zeolites were obtained in several proportions of ash and alkaline solution of $\mathrm{NaOH} ; 1: 2$, $1: 3,1: 4,1: 5,1: 6,1: 7,1: 8,1: 10$. However, the relation $1: 10(\mathrm{~m} / \mathrm{m})$ presented the best chemical and morphological characteristics.

\subsection{Characterization of ash and synthesized zeolite}

To perform the oxide analysis, $300 \mathrm{mg}$ of sample (ashes or zeolites) were dissolved in $2 \mathrm{~mL} \mathrm{HF}$ (hydrofluoric acid, Merck), $3 \mathrm{~mL} \mathrm{HNO}_{3}$ (nitric acid, Merck) and $2 \mathrm{~mL} \mathrm{HCl}$ (hydrochloric acid, Merck) concentrated for digestion in microwave (Provecto Analytical; model: DGT L00 PLUS) oven for 26 minutes. The digestion programming occurs in 5 steps: Step 1 (5 min, $180 \mathrm{~W}$ ); Step 2 (5 min, $0 \mathrm{~W}$ ); Step 3 (5 min, $340 \mathrm{~W}$ ); Step 4 (5 min, $0 \mathrm{~W}$ ); and Step 5 (6 min, $250 \mathrm{~W})$.

After digestion was performed chemical composition analysis of coal ashes and/or zeolites were carried out using the method AOAC (1977) using an Atomic Absorption Spectrophotometer with a Graffiti oven (ETAAS), Model ZEEMAN 220, VARIAN.

Sulfur analysis was performed according to method $4500 \mathrm{SO}_{3}{ }^{2-} \mathrm{B}$ described in Standard Methods for the Examination of Water and Wastewater (APHA, 2012).

\subsection{Melting temperature analysis}

For each ash sample, the following parameters were determined in relation to the melting temperature $\left({ }^{\circ} \mathrm{C}\right)$ : deformation point (d.p.), ballpoint (b.p.), hemisphere point (h.p.) and pour point (p.p.). To perform these determinations, a heating microscope with figure analysis and optical dilatometer Model EM201 (Hesse Instruments) were used, using the standard DIN 51730.

\subsection{Adsorption studies}

\subsubsection{Adsorption of methylene blue dye}

To perform the determination of dye concentration during the kinetic experiments, a calibration curve for the methylene blue was constructed. Initially, using $10 \mathrm{mg} . \mathrm{L}^{-1}$ solutions, a wavelength scan of 300 to $800 \mathrm{~nm}$ was made to determine the wavelength of higher absorbance for methylene blue. The observed wavelength of greatest absorption was $650 \mathrm{~nm}$. To determine the concentration of the dye solutions throughout the experiments, a calibration curve was constructed. For this, solutions were prepared in various concentrations ( 1 to $10 \mathrm{mg}$. $\mathrm{L}^{-1}$ ), whose absorbances were measured in triplicate, and plotted as absorbances versus concentration. The correlation coefficient was $\left(\mathrm{R}^{2}\right) 0.99871$.

The kinetic adsorption of methylene blue dye in batching system was carried out in triplicate. Aqueous solutions were prepared in concentrations of $10 \mathrm{mg} . \mathrm{L}^{-1}, \mathrm{pH} 5$ and environmental temperature $25 \pm 2^{\circ} \mathrm{C}$. The $\mathrm{pH}$ was adjusted with hydrochloric acid solution $1 \mathrm{~mol} . \mathrm{L}^{-1}$. An aliquot of $100 \mathrm{~mL}$ of solution was added to $0.5 \mathrm{~g}$ adsorbent and the suspension was agitated at $60 \mathrm{rpm}$ (magnetic stirrer) by time intervals from 0 to $50 \mathrm{~min}$. At the end of each desired time period, $5 \mathrm{~mL}$ were removed and the solution was separated from the adsorbent by gravitational filtration (filter paper). A supernatant portion was analyzed by spectrophotometry, Model CARY 1G, Varian, at $650 \mathrm{~nm}$.

The adsorption efficiency was calculated using Equation 1:

$R=\frac{100\left(C_{0}-C_{f}\right)}{C_{0}}$ 
Where $\mathrm{R}$ is the adsorption efficiency $(\%), \mathrm{C}_{0}$ is the initial concentration of methylene blue dye $\left(\mathrm{mg} \mathrm{L}^{-1}\right)$ and $\mathrm{Cf}$ is the final concentration of dye in time $\mathrm{t}\left(\mathrm{mg} \mathrm{L}^{-1}\right)$.

The amount of dye adsorbed in the adsorbing stage was quantified according to Equation 2:

$$
q_{(t)}=\frac{V\left(C_{0}-C_{(t)}\right)}{M}
$$

Where $\mathrm{C}_{0}$ is the initial concentration of methylene blue dye $\left(\mathrm{mg} \cdot \mathrm{L}^{-1}\right), \mathrm{C}(\mathrm{t})$ is dye concentration in time $\mathrm{t}\left(\mathrm{mg} . \mathrm{L}^{-1}\right), \mathrm{V}$ is the volume of dye solution (L) and $\mathrm{M}$ is the adsorbent mass $(\mathrm{g})$.

\subsubsection{Heavy metal adsorption}

Kinetic adsorption of metals in batching system was performed in triplicate. Aqueous solutions of iron chloride II (tetrahydrate) and manganese chloride II (tetra hydrate) were prepared in concentrations of $22 \mathrm{mg} . \mathrm{L}^{-1}$ in different $\mathrm{pHs}$ of 5, 7 and 8, and environmental temperature of $25 \pm 2^{\circ} \mathrm{C}$. These $\mathrm{pH}$ values were chosen because at $\mathrm{pH}$ below 5 solubilization of the metals occurs and with $\mathrm{pH}$ above 8 precipitation of the metals under study may occur. The solutions were adjusted to the desired $\mathrm{pH}$ using hydrochloric acid $\left(0,1 \mathrm{~mol} . \mathrm{L}^{-1}\right.$, standard) and sodium hydroxide ( 0.1 mol. $\mathrm{L}^{-1}$, standard). Afterward, an aliquot of $100 \mathrm{~mL}$ of each solution was added to $0.25 \mathrm{~g}$ of adsorbent (zeolite) and the suspension was stirred at $60 \mathrm{rpm}$ (Magnetic stirrer) for time intervals between 0 and $60 \mathrm{~min}$. At the end of each desired time period, $5 \mathrm{~mL}$ were removed and the solution was separated from the adsorbent by gravitational filtration (filter paper). A supernatant portion was analyzed by spectrophotometry, using Spectroquant, Model Nova 60, Merck. The Fe (II) and Mn (II) were quantified in solutions using standard Merck kits. A standard Merck kit was used to assess iron content, determination of iron II, number 14770. To assess manganese, a Merck kit was used, determination of manganese II, number 14896. Equations 1 and 2 were used to evaluate adsorption efficiency and the concentration of metal adsorbed.

\section{RESULTS AND DISCUSSION}

\subsection{Characterization of coal ash samples}

Foremost, the chemical composition of 10 coal ash samples from the Usina Jorge Lacerda, Tractebel Energia, ENGIE, located in the city of Capivari de Baixo, Santa Catarina state, Brazil, was analyzed.

Physical, chemical and mineralogical characteristics of coal fly ash depends on several factors, such as composition of the coal they are made from (precursor), combustion conditions, type and efficiency of the emission control system and disposition methods used. Therefore, generalizing on the chemical composition of ashes or on their behavior in the environment is difficult. However, some characteristics are uniform for most ashes. Fly ashes are considered a ferrous aluminosilicate mineral, with $\mathrm{Al}, \mathrm{Si}, \mathrm{Fe}, \mathrm{Ca}, \mathrm{K}$ and $\mathrm{Na}$ as predominant elements.

Results obtained by chemical composition analysis of ash are shown on Table 1. According to the results presented, silicon oxide is a major composite of the analyzed samples, followed by aluminum, iron and potassium, which together correspond to $76 \%$ of the mass composition of ash samples. 
Table 1. Results of the analysis of chemical composition of ashes in terms of oxides, determined by Atomic Absorption Spectrophotometry with Graffiti oven.

\begin{tabular}{|c|c|c|c|c|c|c|c|c|c|}
\hline Values & $\begin{array}{c}\mathrm{SiO}_{2} \\
(\%)\end{array}$ & $\begin{array}{c}\mathbf{A l}_{2} \mathbf{O}_{3} \\
(\%)\end{array}$ & $\begin{array}{c}\mathrm{Fe}_{2} \mathbf{O}_{3} \\
(\%)\end{array}$ & $\begin{array}{c}\mathbf{K}_{2} \mathbf{O} \\
(\%)\end{array}$ & $\begin{array}{c}\mathrm{CaO} \\
(\%)\end{array}$ & $\begin{array}{l}\mathrm{TiO}_{2} \\
(\%)\end{array}$ & $\begin{array}{c}\mathrm{Na}_{2} \mathrm{O} \\
(\%)\end{array}$ & $\begin{array}{c}\mathrm{MgO} \\
(\%)\end{array}$ & $\begin{array}{l}\mathrm{SO}_{3} \\
(\%)\end{array}$ \\
\hline Average & 63.46 & 6.07 & 4.72 & 1.82 & 0.39 & 1.41 & 0.75 & 0.79 & 0.58 \\
\hline Maximum & 66.98 & 11.32 & 5.10 & 2.65 & 0.87 & 1.76 & 0.84 & 0.29 & 0.82 \\
\hline Minimum & 61.88 & 3.59 & 4.34 & 1.12 & 0.19 & 1.12 & 0.31 & 0.01 & 0.25 \\
\hline Standard deviation & 3.28 & 2.30 & 0.28 & 0.24 & 0.25 & 0.26 & 0.18 & 0.07 & 0.18 \\
\hline
\end{tabular}

Similar values were also observed in other works, like the one carried out by Fallavena et al. (2013), who analyzed coal from the south of Santa Catarina; Van Dyk et al. (2009), who analyzed the coal from South Africa; and Unuma et al. (1986), analyzing coal from the United States of America and in Canada. On the other hand, Song et al. (2009), working with Chinese coal, observed $28 \%$ calcium oxide in ash composition; Ozbayoğlu and Özbayoğlu (2006), studying the coal from Turkey, obtained ashes containing $49.62 \%$ iron oxide, $36.85 \%$ calcium oxide and $32.95 \%$ sulfur oxide, as the maximum values after analyzing several samples. From these results, it is possible to observe that the mining local of coal is fundamental for the chemical composition of ash, which will influence its melting temperature (fusibility).

Results obtained for the melting point analysis are presented in Table 2 . The coal physical composition starts, on average, at $1285^{\circ} \mathrm{C}$, when the deformation point is observed, and it extends until $1456^{\circ} \mathrm{C}$, which is its melting point. There is one variable among the values of the melting point of ash that can be observed and, consequently, influences the physical behavior of different samples of the analyzed ash (melting temperature).

Table 2. Results obtained for analysis of melting point of ash.

\begin{tabular}{lcccc}
\hline Values & d.p. $\left({ }^{\circ} \mathbf{C}\right)$ & b.p. $\left({ }^{\circ} \mathbf{C}\right)$ & h.p. $\left({ }^{\circ} \mathbf{C}\right)$ & p.p. $\left({ }^{\circ} \mathbf{C}\right)$ \\
\hline Average & 1285 & 1376 & 1412 & 1456 \\
Maximum & 1292 & 1383 & 1432 & 1594 \\
Minimum & 1275 & 1363 & 1394 & 1433 \\
Standard deviation & 30 & 7.2 & 12.5 & 7.5 \\
\hline
\end{tabular}

\subsection{Synthesized zeolite characterization}

Hydrothermal synthesis was carried out using two models of reactors, the semi-open system and the closed system. According to the data obtained, the semi-open system became unfeasible for the zeolite synthesis, because it presented low performance (50\%), low purity content and a long time period, about 96 hours for the reaction to occur.

On the other hand, the closed reaction system showed more efficiency when compared with the semi-open system, with a performance over $90 \%$, good purity degree and a reaction time of 24 hours.

In order to characterize the zeolite synthesized by the closed system, analysis of chemical compositions (oxides) were performed. Results showed that silicon oxide is the major composite in the analyzed samples, followed by aluminum, iron, sodium and calcium, that together correspond to over $86 \%$ of mass composition of zeolite samples. In lower concentrations, there are potassium, titanium sulfur and magnesium oxides and other composites in amounts lower than $4 \%$.

In Table 3, the results obtained from the analysis of chemical composition of zeolites synthesized in a closed reactor are shown. 
Table 3. Results of chemical composites of zeolites.

\begin{tabular}{cccccccccc}
\hline Oxides & $\mathrm{SiO}_{2}$ & $\mathrm{Al}_{2} \mathrm{O}_{3}$ & $\mathrm{Fe}_{2} \mathrm{O}_{3}$ & $\mathrm{CaO}$ & $\mathrm{Na}_{2} \mathrm{O}$ & $\mathrm{K}_{2} \mathrm{O}$ & $\mathrm{TiO}_{2}$ & $\mathrm{SO}_{3}$ & $\mathrm{MgO}$ \\
\hline \% in mass & 59.91 & 7.96 & 8.72 & 5.03 & 5.01 & 3.31 & 1.60 & 1.26 & 1.07 \\
\hline
\end{tabular}

Formation of zeolite can be observed during the synthesis process by means of the increase of concentration of some oxides from the ash, mainly by the increase of concentration of aluminum oxide.

According to the results obtained, there was an increase of aluminum and sodium oxides, when compared to the content of these oxides in fly ash. In fly ash, the average content of aluminum oxide was $6.07 \%$, while sodium oxides attained $0.75 \%$. In the synthesized zeolite, the aluminum concentration obtained was $7.96 \%$ and the sodium concentration was $5.01 \%$. The melting point of synthesized zeolite was $1365^{\circ} \mathrm{C}$.

It is important to highlight that the composites responsible for the formation of zeolite before the hydrometric treatment are mainly amorphous $\mathrm{SiO}_{2}$ and $\mathrm{Al}_{2} \mathrm{O}_{3}$. While all the analyzed coal ash samples presented similar percentages of mass for $\mathrm{SiO}_{2}$ and $\mathrm{Al}_{2} \mathrm{O}_{3}$, the amount of these composites is probably different for each coal sample used for the formation of zeolites.

\subsection{Kinetics of adsorption of metals}

According to the data obtained, removal of iron and manganese by adsorbent was fast initially, but decreased gradually with time until 15 minutes (balance time). In order to evaluate the adsorption capacity in the balance time, studies were carried out for adsorption of Fe and Mn, with time from 0 to 15 minutes, $\mathrm{pH}$ 5, 7 and 8.

Figure 1 shows the influence of contact time for ion adsorption of $\mathrm{Fe}(\mathrm{II})$ and $\mathrm{Mn}$ (II) in zeolites, in solutions with $\mathrm{pH} \mathrm{5,7}$ and 8, with initial concentration of $\mathrm{Fe}$ (II) and $\mathrm{Mn}$ (II) equal to $22 \mathrm{mg} . \mathrm{L}^{-1}$. It was possible to verify that the removal increases promptly during the initial stages and the adsorption rate decreases progressively until achieving the start of balance, around 5 minutes. In the first 3 minutes, Fe(II) removal achieved 77.9, 96.3 and $96.8 \%$ with pHs of 5, 7 and 8, respectively. After 10 minutes, removal reached 96, 99 and 99.34\% with pHs of 5, 6 and 7, respectively, corresponding to an average increase of about 19\% (pH 5); 3\% (pH $7)$ and $2.6 \%(\mathrm{pH} 8)$ regarding the first 3 minutes. Kinetics reaches balance in 15 minutes with average removal of $99 \%$, regardless of $\mathrm{pH}$. Similar results were observed for $\mathrm{Mn}$ (II), and, after 15 minutes, a removal of $88.9,99.4$ and $99.77 \%$ with pHs of 5, 7 and 8, respectively, was observed.

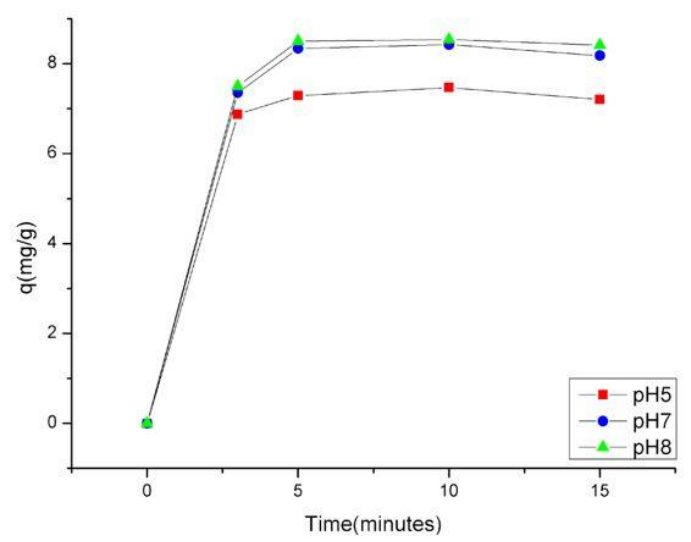

(a)

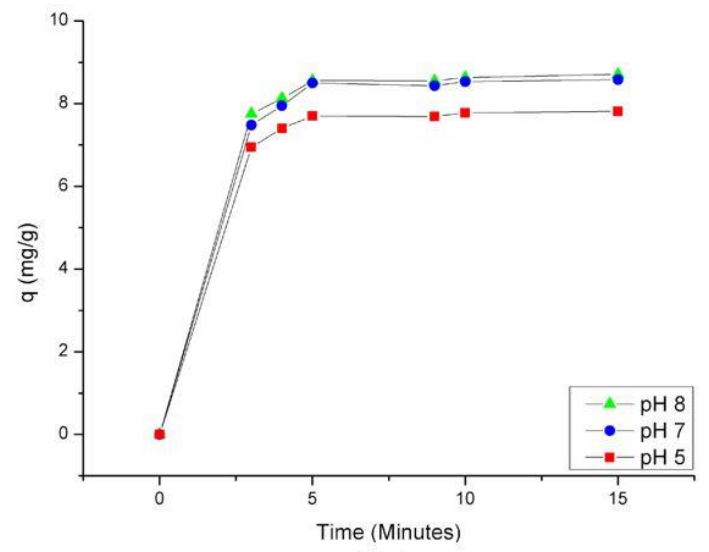

(b)

Figure 1. Results of adsorption of iron (a) and manganese (b) in zeolite in relation to time in different $\mathrm{pH}$ values. 
This velocity of major removal at the start is due to the larger available surface of adsorbent. It is important to highlight that the contact time between adsorbate (Fe and $\mathrm{Mn}$ ) and the adsorbent (zeolite) is very significant for the treatment of water and/or wastewater by adsorption. Fast removal of adsorbate and reaching the balance in a short time period indicates that the adsorbent is very efficient under the evaluated conditions.

Another significant datum is the occurrence of a simple and continuous shape of the curve until the saturation, what suggests a metal monolayer cover on the zeolite surface.

Comparing the results obtained for adsorption of iron and manganese ions in different $\mathrm{pHs}$, we observed that the best results were obtained at basic $\mathrm{pH}(\mathrm{pH} \mathrm{8)}$, regardless of the metal analyzed. Chemically, the basic $\mathrm{pH}$ provides metal adsorption, because in a basic medium metal can become rusty, and this facilitates interactions between the adsorbate (metal) and the adsorbent. At $\mathrm{pH}$ below 5, the solubilization of metals occurs, and at $\mathrm{pH}$ above 8 occurs the precipitation of the metals which hinders adsorption.

These results prove that under the conditions studied the use of active zeolite is a good adsorbent of water contaminants such as iron and manganese, since it is a strong cationic changer and promotes a good chemical interaction with the molecules of the adsorbate

Data still showed that kinetic studies are important to determine the balance time. The time is balanced when the amount of adsorbate that is being adsorbed by the adsorbent is in dynamic balance with the amount of adsorbate that is being desorbed. The time required to achieve the balance state reflects the maximum capacity of adsorbate by adsorbent under determined operational conditions.

Kinetic parameters are also important to evaluate the velocity of adsorption and are used to develop the kinetic models, and then understand what parameters influence the adsorption process. Several mathematical models in the literature describe the kinetics of adsorption. Among them, we can highlight the kinetics described by the models of pseudo-first-order, pseudo-second-order and intraparticle diffusion. The application of these models depends on the experimental data obtained.

Kinetic equation of pseudo-first-order is widely used to forecast the kinetics of adsorption of some elements/composites. In this model, velocity of adsorption can be determined by a velocity expression of pseudo-first-order by Lagergren (1898), for adsorption in a liquid-solid system based on the solid adsorption capacity. Lagergren presumed that the adsorbate velocity of removal, with time, is directly proportional to the difference in the concentration of saturation and the number of solid active sites. The Lagergren kinetic equation is the most used one for adsorption of an adsorbate of aqueous solution. Equation 3 gives the linear form of the pseudofirst-order:

$\log _{10}(q e-q)=\log _{10} q e-\frac{k_{1}}{2,303} t$

Where $q e$ and $q$ are amounts of metals adsorbed $\left(\mathrm{mg}^{-\mathrm{g}^{-1}}\right)$ in balance and in time $\mathrm{t}(\mathrm{min})$, respectively; $\mathrm{k}_{1}$ is the constant of velocity of adsorption $\left(\mathrm{min}^{-1}\right)$. The constant $\mathrm{k}_{1}$ can be calculated from the inclination of the straight of the graph $\log (q e-q) v s \mathrm{t}$.

The results obtained were also analyzed using the model of pseudo-second-order developed by Ho and colleagues (1996), in which the velocity of reaction depends on the solute adsorbed amount on the adsorbent surface and the amount adsorbed in balance. The linear model of pseudo-second-order is represented by the Equation 4:

$\frac{\mathrm{t}}{\mathrm{q}}=\frac{1}{k_{2} q_{e}^{2}}+\frac{1}{q e} \mathrm{t}$ 
Where $q e$ and $q t$ are the amount metals $\left(\mathrm{Fe}\right.$ and $\mathrm{Mn}$ ) adsorbed $\left(\mathrm{mg} \cdot \mathrm{g}^{-1}\right)$ in balance and time $\mathrm{t}(\mathrm{min}) ; \mathrm{k}_{2}$ is the constant of velocity of pseudo-second-order $\left(\mathrm{mg} \cdot \mathrm{g}^{-1} \cdot \mathrm{min}^{-1}\right)$. According to the data of the straight of the graph $\mathrm{t} / \mathrm{q}$ versus $\mathrm{t}$, the values of $\mathrm{k}_{2}\left(\mathrm{~g} \cdot \mathrm{mg}^{-1} \cdot \mathrm{min}^{-1}\right)$ and $q e\left(\mathrm{mg} \cdot \mathrm{g}^{-1}\right) \mathrm{can}$ be calculated. In contrast with the kinetic model of pseudo-first order, there is no need to know some previous parameters, because this model already forecasts the behavior on the complete adsorption period and it occurs according to an adsorption mechanism responsible by the velocity control stage.

Kinetic models previously described usually cannot describe the kinetic adsorption. Then, the intraparticle diffusion model can be used. According to Weber and Morris (1963), if the intraparticle diffusion is a determinant factor for velocity, the adsorbate removal varies according to the square root of time. Therefore, the intraparticle diffusion coefficient $\left(\mathrm{k}_{\mathrm{di}}\right)$ is determined by Equation 5:

$q_{t}=k_{d i} t^{1 / 2}+\mathrm{C}$

Where $q t$ is the adsorbed metal amount $\left(\mathrm{mg} \mathrm{g}^{-1}\right), \mathrm{t}(\mathrm{min})$ is the stirring time and $\mathrm{C}\left(\mathrm{mg}_{\mathrm{g}} \mathrm{g}^{-1}\right)$ is a constant related to the diffusion strengthening.

According to Equation 5, values of $\mathrm{k}_{\mathrm{di}}\left(\mathrm{mg} \mathrm{g}^{-1} \cdot \mathrm{min}^{-1 / 2}\right)$ and $\mathrm{C}$ can be obtained by inclination and intersection of the graph curve $q_{t} v s t^{1 / 2}$, respectively. C values provide an idea about the thickness of the limit layer; in other words, the higher the $\mathrm{C}$ value, the higher the effect from the boundary (Dizge et al., 2008). There are studies showing that the graph can present multilinearity, which characterizes different adsorption stages: external mass transference followed by diffusion macro, meso and micro pore.

Tables 4 and 5 show the kinetic parameters of iron and manganese adsorption by synthesized zeolite, which were obtained by linear regression of curves for each model (Figures 2 and 3$)$.

Table 4. Kinetic parameters for iron removal by zeolite.

\begin{tabular}{|c|c|c|c|c|c|c|c|}
\hline \multicolumn{8}{|c|}{ Pseudo-first-order } \\
\hline & pH & Metal (mg. $\left.\mathrm{L}^{-1}\right)$ & $\begin{array}{c}\mathbf{K}_{\mathbf{1}} \\
\left(\min ^{-1}\right)\end{array}$ & $\begin{array}{c}\text { qecalc } \\
\left(\mathrm{mg} \cdot \mathrm{g}^{-1}\right)\end{array}$ & $\mathbf{q e}_{\text {exp. }}\left(\mathrm{mg} \cdot \mathrm{g}^{-1}\right)$ & $\mathbf{R}^{2}$ & \\
\hline & 5 & 22 & 1.2802 & 4.9946 & 7.0733 & 0.9522 & \\
\hline & 7 & 22 & 0.7738 & 6.3067 & 7.9253 & 0.9751 & \\
\hline & 8 & 22 & 0.7028 & 6.5690 & 8.2467 & 0.9753 & \\
\hline \multicolumn{8}{|c|}{ Pseudo-second-order } \\
\hline & pH & $\begin{array}{c}\text { Metal } \\
\left(\mathrm{mg} \cdot \mathrm{L}^{-1}\right)\end{array}$ & $\begin{array}{c}\mathbf{K}_{\mathbf{2}} \\
\left(\mathrm{mg} \cdot \mathrm{g}^{-1} \cdot \mathrm{min}^{-1}\right)\end{array}$ & $\begin{array}{c}\mathbf{q e} \text { calc } \\
\left(\mathrm{mg} \cdot \mathrm{g}^{-1}\right)\end{array}$ & $\begin{array}{c}\text { qeexp. } \\
\left(\mathrm{mg} \cdot \mathrm{g}^{-1}\right)\end{array}$ & $\mathbf{R}^{2}$ & \\
\hline & 5 & 22 & 1.3158 & 7.0621 & 7.0733 & 0.9999 & \\
\hline & 7 & 22 & 1.3881 & 7.9365 & 7.9253 & 0.9998 & \\
\hline & 8 & 22 & 0.6053 & 8.2508 & 8.2467 & 0.9999 & \\
\hline \multicolumn{8}{|c|}{ Intraparticle diffusion } \\
\hline pH & $\begin{array}{c}\text { Metal } \\
\left(\mathrm{mg} . \mathrm{L}^{-1}\right)\end{array}$ & $\begin{array}{c}\mathbf{K}_{\text {di1 }} \\
\left(\mathrm{mg} \cdot \mathrm{g}^{-1} \cdot \mathrm{t}^{-1 / 12}\right)\end{array}$ & $\mathbf{R}_{1}{ }^{2}$ & $\mathbf{C}_{1}$ & $\begin{array}{c}\mathbf{K}_{\mathbf{d i 2}} \\
\left(\mathrm{mg} \cdot \mathrm{g}^{-1} \cdot \mathrm{t}^{-1 / / 2}\right)\end{array}$ & $\mathbf{R}_{2}^{2}$ & $\mathbf{C}_{2}$ \\
\hline 5 & 22 & 0.05514 & 0.92327 & 7.353508 & 0.05514 & 0.92327 & 8.81856 \\
\hline 7 & 22 & 0.31535 & 0.61319 & 7.20586 & 0.0049 & 0.09338 & 7.9245 \\
\hline 8 & 22 & 0.3428 & 0.6603 & 7.296 & -0.0002 & -0.0127 & 8.26204 \\
\hline
\end{tabular}


Table 5. Kinetic parameters for manganese removal by zeolite.

\begin{tabular}{|c|c|c|c|c|c|c|c|}
\hline \multicolumn{8}{|c|}{ Pseudo-first-order } \\
\hline & pH & $\begin{array}{c}\text { Metal } \\
\left(\mathrm{mg} \cdot \mathrm{L}^{-1}\right)\end{array}$ & $\begin{array}{c}\mathbf{K}_{\mathbf{1}} \\
\left(\min ^{-1}\right)\end{array}$ & $\begin{array}{c}\mathbf{q e}_{\text {calc }} \\
\left(\mathrm{mg} \cdot \mathrm{g}^{-1}\right)\end{array}$ & $\begin{array}{c}\mathbf{q e}_{\text {exp. }} \\
\left(\mathrm{mg} \cdot \mathrm{g}^{-1}\right)\end{array}$ & $\mathbf{R}^{2}$ & \\
\hline & 5 & 22 & 0.5327 & 4.5123 & 7.8120 & 0.9021 & \\
\hline & 7 & 22 & 0.5161 & 4.6409 & 8.5800 & 0.8364 & \\
\hline & 8 & 22 & 0.4645 & 4.5426 & 8.7093 & 0.8551 & \\
\hline \multicolumn{8}{|c|}{ Pseudo-second-order } \\
\hline & pH & $\begin{array}{c}\text { Metal } \\
\left(\mathrm{mg} \cdot \mathrm{L}^{-1}\right)\end{array}$ & $\begin{array}{c}\mathbf{K}_{\mathbf{2}} \\
\left(\mathrm{mg} \cdot \mathrm{g}^{-1} \cdot \mathrm{min}^{-1}\right)\end{array}$ & $\begin{array}{c}\mathbf{q e}_{\text {calc }} \\
\left(\mathrm{mg} \cdot \mathrm{g}^{-1}\right)\end{array}$ & $\begin{array}{c}\mathbf{q e}_{\text {exp. }} \\
\left(\mathrm{mg} \cdot \mathrm{g}^{-1}\right)\end{array}$ & $\mathbf{R}^{2}$ & \\
\hline & 5 & 22 & 1.2511 & 7.8864 & 7.8120 & 0.9994 & \\
\hline & 7 & 22 & 1.5239 & 8.6730 & 8.5800 & 0.9991 & \\
\hline & 8 & 22 & 1.4336 & 8.7796 & 8.7093 & 0.9994 & \\
\hline \multicolumn{8}{|c|}{ Intraparticle diffusion } \\
\hline pH & $\begin{array}{c}\text { Metal } \\
\left(\mathrm{mg} . \mathrm{L}^{-1}\right)\end{array}$ & $\begin{array}{c}\mathbf{K}_{\text {di1 }} \\
\left(\mathrm{mg} \cdot \mathrm{g}^{-1} \cdot \mathrm{t}^{-1 / 2}\right)\end{array}$ & $\mathbf{R}_{1}^{2}$ & $\mathbf{C}_{1}$ & $\begin{array}{c}\mathbf{K}_{\text {di } 2} \\
\left(\mathrm{mg} \cdot \mathrm{g}^{-1} \cdot \mathrm{t}^{-1 / 2}\right)\end{array}$ & $\mathbf{R}_{2}^{2}$ & $\mathbf{C}_{2}$ \\
\hline 5 & 22 & 1.49044 & 0.99701 & 4.34807 & 0.11601 & 0.83819 & 7.36975 \\
\hline 7 & 22 & 2.01485 & 0.99642 & 3.9682 & 0.13678 & 0.85057 & 8.05818 \\
\hline 8 & 22 & 1.58791 & 0.99684 & 4.98573 & 0.15766 & 0.9426 & 8.10394 \\
\hline
\end{tabular}

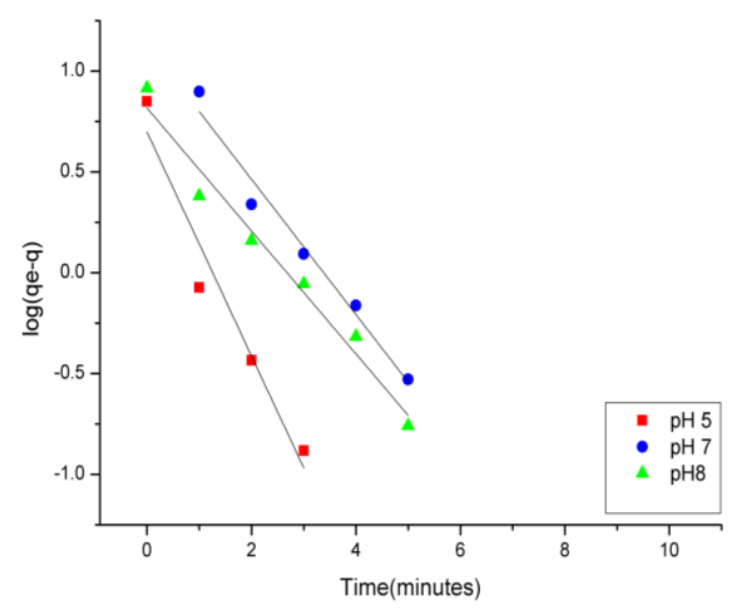

(a)

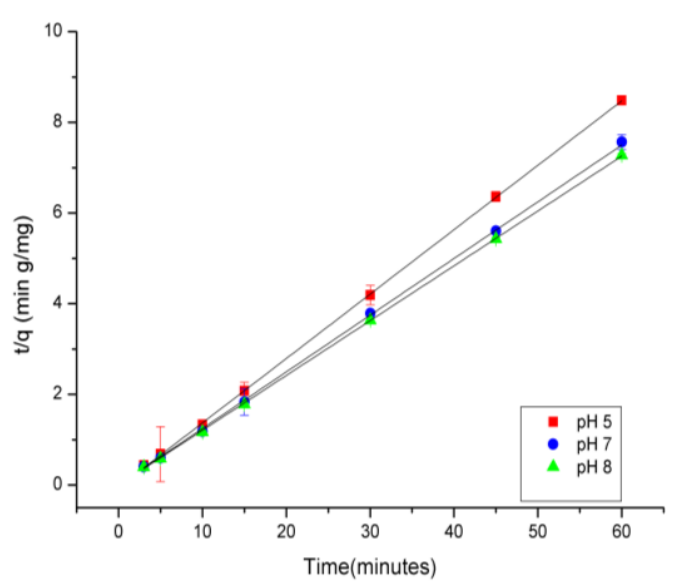

(b)

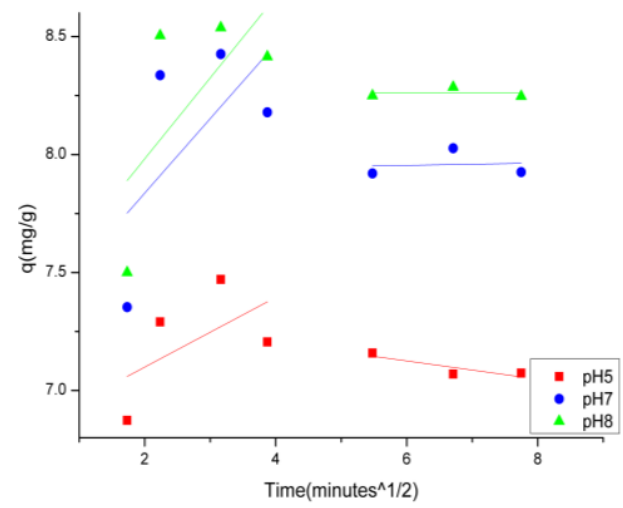

(c)

Figure 2. Kinetic models of ion adsorption of iron on zeolite: (a) pseudo-first-order; (b) pseudo-second-order; (c) Intraparticle diffusion. 


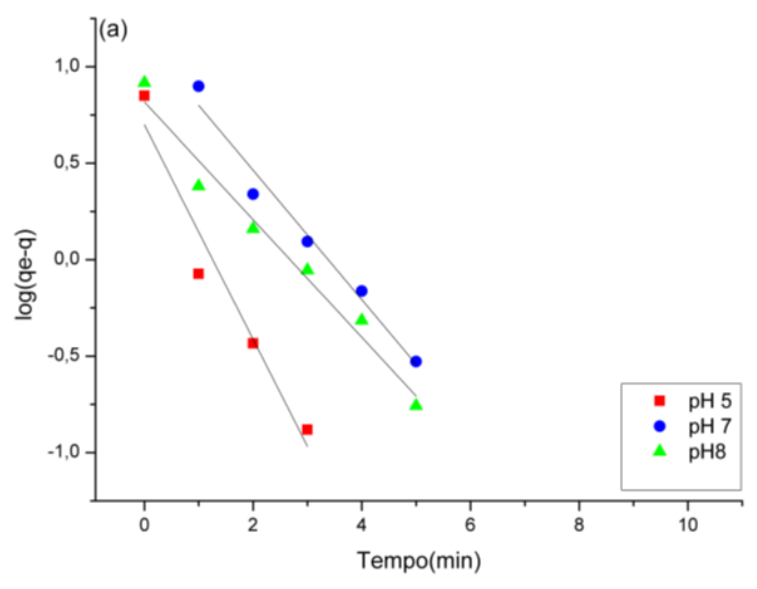

(a)

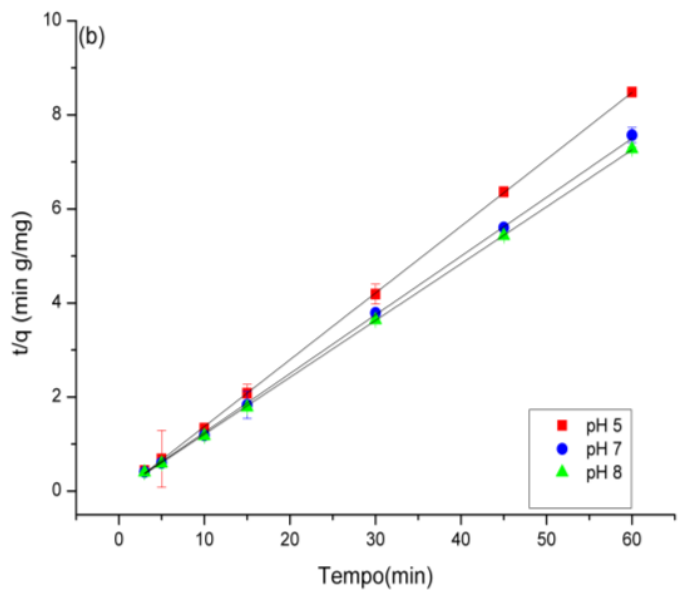

(b)

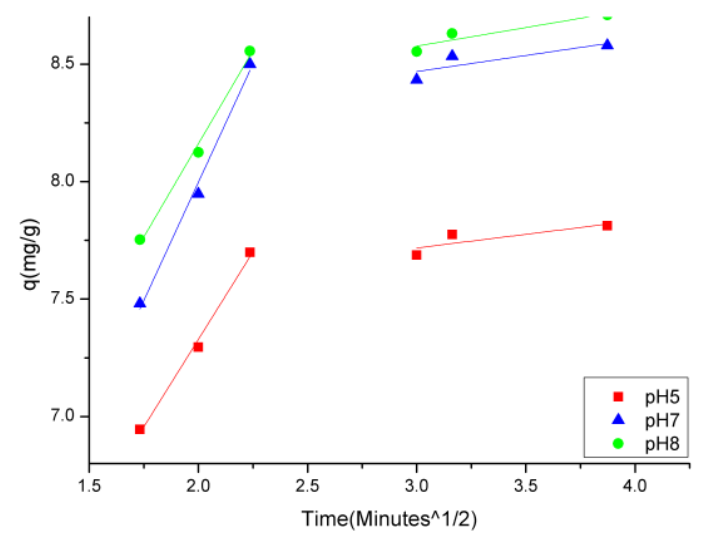

(c)

Figure 3. Kinetic models of ion adsorption of manganese on zeolite: (a) pseudo-firstorder; (b) pseudo-second-order; (c) Intraparticle diffusion.

A quantitative evaluation of the models studied was performed by comparison of correlation coefficients (R2) and by calculated qe versus qe obtained experimentally.

When comparing data from Tables 4 and 5 with the correlation coefficient values calculated for Lagergren's pseudo-first-order and Ho's pseudo-second-order kinetic models, the values were higher than 0.9 , which shows the applicability of both kinetic models. Tables 4 and 5 also show the kinetic parameters for each studied model.

Figures 2 and 3 show the experimental results obtained with Lagergren's and Ho's models and intraparticle diffusion. The results analyzed show that the pseudo-second-order model (by Ho) presented lower error when compared to Lagergren's (pseudo-first-order). Lagergren's model presented a theoretical value well below the experimental value, despite its good linear correlation (Tables 4 and 5). Further, when comparing the constant of velocity for both models, k2 (Ho's model) is about 2 times higher than $\mathrm{k}_{1}$ (Lagergren's model), regardless of the $\mathrm{pH}$ and the metal (Fe and $\mathrm{Mn}$ ) analyzed.

Still, the good concordance of theoretical results of Ho's model with experimental data is observed. It suggests the control of velocity must occur as an active or chemisorption mechanism.

In order to obtain information on the mechanisms that affect the kinetic adsorption, experimental results were applied to the intraparticle diffusion model proposed by Weber and Morris (1963).

\section{IPABH}


Figures 2C and 3C show the diffusion model proposed by Weber and Morris (1963). According to this model, if intrapore diffusion is the stage that controls adsorption, then the graph $q t v s t^{1 / 2}$ will result in a straight line and its angular coefficient will correspond to the diffusion constant $\mathrm{k}_{\mathrm{di}}\left(\mathrm{mg} \cdot \mathrm{g}^{-1} \cdot \mathrm{min}^{-1 / 2}\right)$. In practice, the process is not simple, because it involves several straight segments in which each equation corresponds to an adsorption stage. The balance is reached when the adsorption capacity $q\left(\mathrm{mg} \mathrm{g}^{-1}\right)$ does not change over time and the line observed is horizontal. This model suggests that, if the first straight segment (adsorption initial stage) has a linear coefficient equal to zero (in other words, the straight segment cuts the origin), then intrapore diffusion controls the adsorption process. However, if the linear coefficient is different from zero, then the process that controls the adsorption might be an intrafilm diffusion, whose thickness is attributed to the linear coefficient in $\mathrm{mg} \cdot \mathrm{g}^{-1}$.

Figure $2 \mathrm{C}$ shows the stages involved in $\mathrm{Fe}(\mathrm{II})$ adsorption on the zeolite adsorbent surface. For time interval 0-10 minutes, the linear coefficients were different from zero and the diffusion coefficients at $\mathrm{pHs}$ of 5,6 and 7 were $\mathrm{kdi}=0.055,0.415$ and $0.343 \mathrm{mg} \cdot \mathrm{g}^{-1} \cdot \mathrm{t}^{-1 / 2}$, respectively.

Similar results were obtained for Mn (II), as shown in Figure 3C. Diffusion coefficients at $\mathrm{pHs}$ of 5, 6 and 7 were $\mathrm{kdif}(\mathrm{I})=1.490,2.014$ and $1.587 \mathrm{mg} \cdot \mathrm{g}^{-1} . \mathrm{t}^{-1 / 2}$, respectively .

In stage II, both for $\mathrm{Fe}(\mathrm{II})$ and $\mathrm{Mn}(\mathrm{II})$, there is reduction of the diffusion constant until reaching balance. Tables 4 and 5 show the parameter values for the Stages I and II. Figures $2 \mathrm{C}$ and $3 \mathrm{C}$ show the time in which the change from one stage to another occurs along the adsorption process. According to the results, the Webber-Morris model does not allow easy knowledge what happens near $\mathrm{t}=0$. It is therefore not possible to foresee whether intrapore diffusion predominates during the initial stages (previous to Stage I in the graph).

\subsection{Adsorption kinetic of methylene blue dye}

Data obtained from the calibration curve were used to evaluate the kinetics of dye removal. Removal was calculated through the difference between the initial and final methylene blue dye concentration in a determined time interval, using the zeolite as adsorbent. Data obtained are shown on Figure 4.

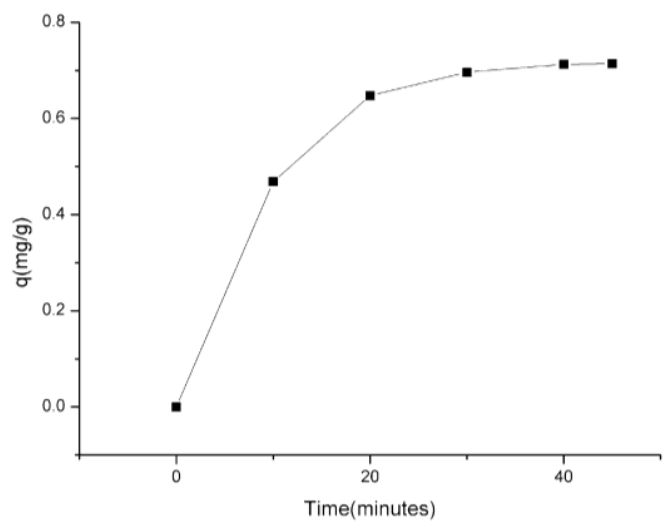

Figure 4. Results of kinetic adsorption of methylene blue in zeolite over time.

According to the results, it is possible to observe that the balance time was about 30 minutes and the adsorption efficiency average was above $90 \%$. In addition, when the starting process occurred, the competition of methylene blue molecules by the active sites of adsorbent molecules was higher, and then, a higher concentration of dye was adsorbed in the first 10 minutes, near 50\%. Data obtained from the adsorption process of methylene blue by zeolite were analyzed applying Lagergren's pseudo-first-order, Ho's pseudo-second-order kinetic models and the intraparticle diffusion model. 
Figure 5 shows the results of the adsorption process of methylene blue in zeolites applying the kinetic models previously described. Kinetic parameters obtained by data treatment for the different models are shown on Table 6.

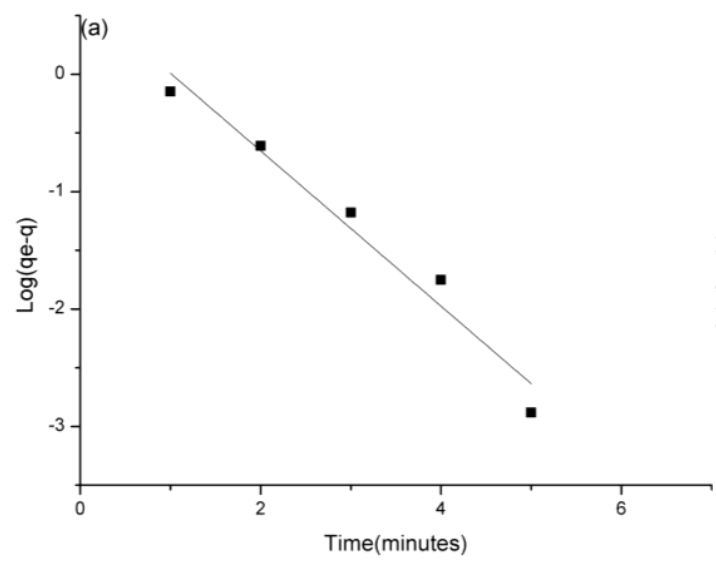

(a)

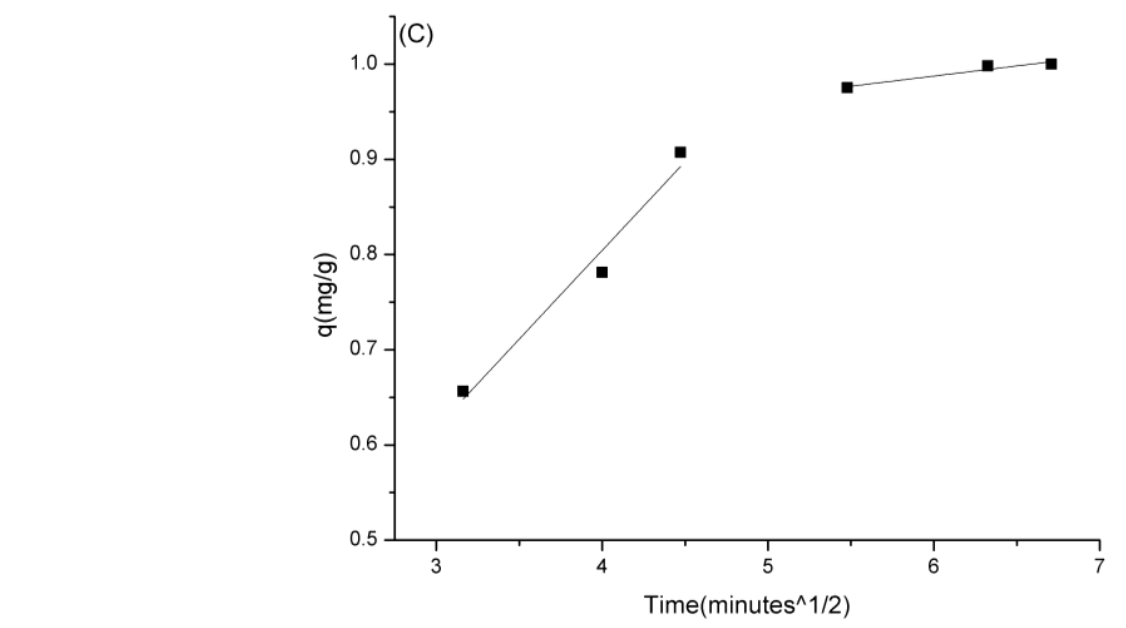

(c)

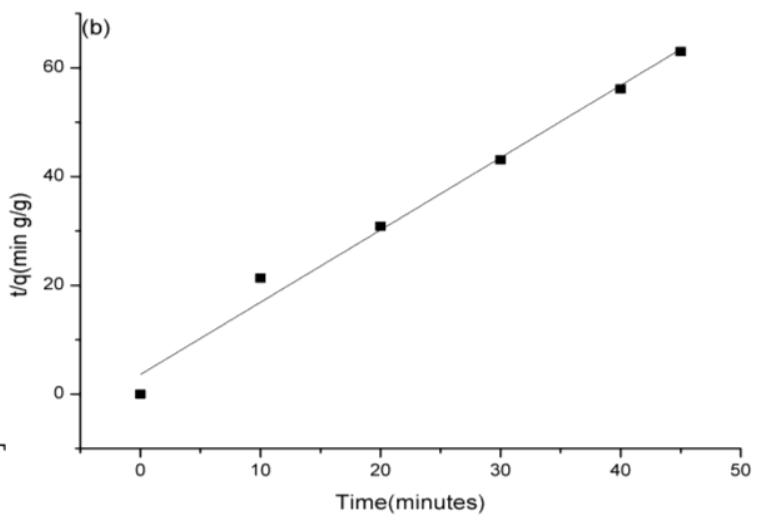

(b)

Figure 5. Kinetic models for adsorption of Methylene blue over zeolite: (a) pseudo-first-order; (b) pseudo-second-order; (c) intraparticle.

Table 6. Kinetic parameters for methylene blue removal by zeolite applying different kinetic models.

\begin{tabular}{|c|c|c|c|c|c|c|}
\hline & \multicolumn{6}{|c|}{ Pseudo-first-order } \\
\hline & $\begin{array}{c}\text { Dye } \\
\left(\mathrm{mg} \cdot \mathrm{L}^{-1}\right)\end{array}$ & $\begin{array}{c}\mathbf{K}_{\mathbf{1}} \\
\left(\min ^{-1}\right)\end{array}$ & $\begin{array}{c}\mathbf{q e}_{\text {calc }} \\
\left(\mathrm{mg} \cdot \mathrm{g}^{-1}\right)\end{array}$ & $\begin{array}{c}\mathbf{q e}_{\text {exp. }} \\
\left(\mathrm{mg} \cdot \mathrm{g}^{-1}\right)\end{array}$ & $\mathbf{R}^{2}$ & \\
\hline & 22 & 0.15236 & 1.0205 & 0.7141 & 0.9659 & \\
\hline & \multicolumn{6}{|c|}{ Pseudo-second-order } \\
\hline & $\begin{array}{c}\text { Dye } \\
\left(\mathrm{mg} . \mathrm{L}^{-1}\right)\end{array}$ & $\begin{array}{c}\mathbf{K}_{\mathbf{2}} \\
\left(\mathrm{mg} \cdot \mathrm{g}^{-1} \cdot \mathrm{min}^{-1}\right)\end{array}$ & $\begin{array}{c}\mathbf{q e}_{\text {calc }} \\
\left(\mathrm{mg} \cdot \mathrm{g}^{-1}\right)\end{array}$ & $\begin{array}{c}\mathbf{q e}_{\text {exp. }} \\
\left(\mathrm{mg} \cdot \mathrm{g}^{-1}\right)\end{array}$ & $\mathbf{R}^{2}$ & \\
\hline & 22 & 0.54370 & 0.7522 & 0.7141 & 0.9876 & \\
\hline & \multicolumn{6}{|c|}{ Intraparticle diffusion } \\
\hline $\begin{array}{c}\text { Dye } \\
\left(\mathrm{mg} \cdot \mathrm{L}^{-1}\right)\end{array}$ & $\begin{array}{c}\mathbf{K}_{\mathrm{di} \mathbf{1}} \\
\left(\mathrm{mg} \cdot \mathrm{g}^{-1} \cdot \mathrm{t}^{-1 / 2}\right)\end{array}$ & $\mathbf{R}_{1}^{2}$ & $\mathbf{C}_{1}$ & $\begin{array}{c}\mathbf{K}_{\mathrm{di2} 2} \\
\left(\mathrm{mg} \cdot \mathrm{g}^{-1} \cdot \mathrm{t}^{-1 / 2}\right)\end{array}$ & $\mathbf{R}_{2}^{2}$ & $\mathbf{C}_{2}$ \\
\hline 22 & 0.1864 & 0.98681 & 0.0586 & 0.02129 & 0.97064 & 0.85977 \\
\hline
\end{tabular}


By means of the analysis of the kinetic data, the application of kinetic models studied was observed, because the correlation coefficients $\left(\mathrm{R}^{2}\right)$ were higher than 0.9 , regardless of the model studied. However, when comparing the constant velocity for the both models, $\mathrm{k}_{2}\left(0.54370 \mathrm{mg} \cdot \mathrm{g}^{-1} \cdot \mathrm{min}^{-1}\right)$ is about 4 times higher than $\mathrm{k}_{1}\left(0.15236 \mathrm{~min}^{-1}\right)$. Besides, the pseudosecond-order model (by Ho) presented lower error when compared to the Lagergren one (pseudo-first-order). Lagergren's model presented a theoretical value (1.0205 mg. $\left.\mathrm{g}^{-1}\right)$ above the experimental value $\left(0.7141 \mathrm{mg} \mathrm{g}^{-1}\right)$, despite the good linear correlation (Table 6). This indicates that the model which better adjusts to experimental data was Ho's model.

When analyzing data from the intraparticle diffusion graph, it is observed that the correlation coefficient was higher than 0.9 and the line did not pass by the origin, which indicates this stage is not decisive for adsorption velocity. Figure $5 \mathrm{C}$ shows the stages involved in the adsorption of methylene blue in zeolite. At a time interval of 0-20 minutes, the linear coefficient was different from zero, with a value equal to 0.0586 . The diffusion coefficient for this stage was $\mathrm{kdi}=0,1864 \mathrm{mg} \cdot \mathrm{g}^{-1} \cdot \mathrm{t}^{-1 / / 2}$.

In Stage II, there was a constant reduction of diffusion from 0.1864 to $0.02129 \mathrm{mg} \cdot \mathrm{g}^{-1} \cdot \mathrm{t}^{-1 / 2}$ until balance was achieved.

Table 6 shows the values of parameters for Stages I and II. Figure 5C shows the time in which the change from one stage into another occurs along the adsorption process. The WebberMorris model does not allow knowledge of what happens near $\mathrm{t}=0$. It is therefore impossible to estimate whether intrapore diffusion predominates or not in initial stages (prior to the Stage I in the graph). Some kinetic studies on the adsorption of methylene blue in zeolite showed similar results. In other words, the process followed the velocity expression of pseudo-secondorder. These studies used synthetic and natural zeolite clinoptilolite as adsorbent materials (Wang and Wu, 2006; Wang and Zhu, 2006; Wang et al. 2009).

\section{CONCLUSIONS}

Kinetic data showed that the adsorption of iron, manganese and dye increases faster during the initial stages and that the adsorption rate decreases progressively until achieving the beginning balance. Kinetic models reach equilibrium in 15 minutes, with a removal rate of $99 \%$ for iron and manganese and $90 \%$ of methylene blue dye.

Kinetic studies also showed that the model which better corroborates the experimental data is the pseudo-second-order model by Ho. Studies on intraparticle diffusion showed multilinearity, which characterizes the different stages of adsorption of metal and dye, like the external mass transference, followed by diffusion macro, meso and micropore.

Finally, the zeolite synthesized from mineral coal fly ash revealed potential to be used as an alternative material to remove metals such as Fe and Mn and dye from wastewater. Further, if the mineral coal fly ash is not appropriately discarded, as an adsorbent raw material they are a continuous source of pollution in the environment.

\section{ACKNOWLEDGEMENTS}

The authors are thankful to FAPESC and UNISUL for the financial support to carry out this project.

\section{REFERENCES}

ABDELRASOUL, A.; ZHANG, H.; CHENG, C.H.; DOAN, H. Applications of molecular simulations for separation and adsorption in zeolites. Microporous and Mesoporous Materials, v. 242, p. 294-348, 2017. http://dx.doi.org/10.1016/j.micromeso.2017.01.038 
AMERICAN PUBLIC HEALTH ASSOCIATION - ALPHA. Standard Methods for the Examination of Water \& Wastewater. 22. ed. Washington, 2012.

AOAC INTERNATIONAL. Official methods of analysis. 16. ed. Gaithersburg, 1977.

ATTARI, M.; SALMAN BUKHARI, S.; KAZEMIAN, H.; ROHANI, S. A Low-Cost Adsorbent from Coal Fly Ash for Mercury Removal from Industrial Wastewater. Journal of Environmental Chemical Engineering, v. 5, n. 1, p. 391-399, 2017. http://dx.doi.org/10.1016/j.jece.2016.12.014

AYELE, L.; PÉREZ-PARIENTE, J.; CHEBUDE, Y.; DIAZ, I. Synthesis of zeolite A using kaolin from Ethiopia and its application in detergents. New Journal of Chemistry, n. 4, 2016. http://dx.doi.org/10.1039/C5NJ03097H

BRUNO, M. Utilização de zeólitas sintetizadas a partir de cinzas de carvão na remoção de corante em água. 2008. Dissertação (Mestrado) - Instituto de Pesquisas Energéticas e Nucleares (IPEN), São Paulo, 2008.

BUKHARI, S. S.; BEHIN, J.; KAZEMIAN, H.; ROHANI, S. Conversion of coal fly ash to zeolite utilizing microwave and ultrasound energies: A review. Fuel, v. 140, p. 250-266, 2014. http://dx.doi.org/10.1016/j.fuel.2014.09.077

CALUGARU, I. L.; NECULITA, C. M.; GENTY, T.; ZAGURY, G. J. Metals and metalloids treatment in contaminated neutral effluents using modified materials. Journal of $\begin{array}{llllll}\text { Environmental Management, } & \text { v. 212, } & \text { p. } & 142-159, & \end{array}$ https://doi.org/10.1016/j.jenvman.2018.02.002

CARDOSO, A. M.; PAPROCKI, A.; FERRET, L. S.; AZEVEDO, C. N.; PIRES, M. Synthesis of zeolite Na-P1 under mild conditions using Brazilian coal fly ash and its application in wastewater treatment, Fuel, v. 139, p. 59-67, 2015a. https://doi.org/10.1016/j.fuel.2014.08.016

CARDOSO, A.; HORN, M.; FERRET, L.; AZEVEDO, C.; PIRES, M. Integrated synthesis of zeolites $4 \mathrm{~A}$ and $\mathrm{Na}-\mathrm{P} 1$ using coal fly ash for application in the formulation of detergents and swine wastewater treatment. Journal of Hazardous Materials, v. 287, p. 69-77, 2015b. http://dx.doi.org/10.1016/j.jhazmat.2015.01.042

CUNICO, P.; MAGDALENA, P.; CARVALHO, E. T.; FUNGAROD, A. D. M. Adsorção de Corante Reativo Preto 5 em Solução Aquosa Utilizando Cinzas Leves de Carvão. In: INTERNATIONAL WORKSHOP ADVANCES IN CLEANER PRODUCTION, 2., 2009, São Paulo. Resumos... Disponível em: https://goo.gl/QihhPR. Acesso em: maio 2018.

DASSEKPO, J. B. M.; ZHA, X.; ZHAN, J. Synthesis reaction and compressive strength behavior of loess-fly ash based geopolymers for the development of sustainable green materials. Construction and Building Materials, v. 141, p. 491-500, 2017. http://dx.doi.org/10.1016/j.conbuildmat.2017.03.034

DIZGE, N.; AYDINER, C.; DEMIRBAS, E.; KOBYA, M.; KARA, S.; J. Adsorption of reactive dyes from aqueous solutions by fly ash: kinetic and equilibrium studies. Hazard Materials, v. 150, p. 737-746, 2008. http://dx.doi.org/10.1016/j.jhazmat.2007.05.027

FALLAVENA, V. L. V.; ABREU, C. S. DE; INÁCIO, T. D.; PIRES, M.; AZEVEDO, C. M. N. Caracterização detalhada de material de referência certificado de carvão brasileiro. Química Nova, v. 36, n. 6, p. 859-864, 2013 
FUKASAWA, T.; KARISMA, A.; SHIBATA, D.; HUANG, A.; FUKUI, K. Synthesis of zeolite from coal fly ash by microwave hydrothermal treatment with pulverization process. Advanced Powder Technology, v. 150, p. 737-746, 2017. https://dx.doi.org/10.1016/j.apt.2016.12.006

HEMALATHA, T.; RAMASWAMY, A. A review on fly ash characteristics- Towards promoting high volume utilization in developing sustainable concrete. Journal of $\begin{array}{llllll}\text { Cleaner Production, } & \text { v. 147, } & \text { p. }\end{array}$ http://dx.doi.org/10.1016/j.jclepro.2017.01.114

HO, Y. S.; WASE, D. A. J.; FORSTER, C. F. Kinetic Studies of Competitive Heavy Metal Adsorption by Sphagnum Moss Peat. Environmental Technology, v. 17, p. 71-77, 1996.

ITSKOS, G. A.; KOUTSIANOS, N.; KOUKOUZAS, C.; VASILATOS. Zeolite development from fly ash and utilization in lignite mine-water treatment. International journal of mineral processing, v. 139, p. 43-50, 2015. http://dx.doi: 10.1016/j.minpro.2015.04.01

KNOX, A. S.; PALLER, M. H.; MILliKEN, C. E.; REDDER, T. M.; WOLFE, J. R.; SEAMAN, J. Environmental impact of ongoing sources of metal contamination on remediated sediments. Science of the Total Environment, v. 563-564, p. 108-117, 2016. http://dx.doi.org/10.1016/j.scitotenv.2016.04.050

LAGERGREN, S. Zur theorie der sogenannten adsorption geloster stoffe. Kungliga Svenska Vetenskapsakademiens. Handlingar, v. 24, p. 1-39, 1898.

LEE, Y. R.; SOE, J. T.; ZHANG, S.; AHN, J. W.; PARK, M. B.; AHN, W. S. Synthesis of Nanoporous Materials via Recycling Coal Fly Ash and Other Solid Wastes: A Mini Review, Chemical Engineering Journal, v. 317, p. 821-843, 2017. http://dx.doi.org/10.1016/j.cej.2017.02.124

LUOA, Y.; SHUHUA MAA, B.; LIUA, C.; ZHAOA, Z.; ZHENGA, S.; WANG, I.X. Effect of particle size and alkali activation on coal fly ash and their rolein sintered ceramic tiles. Journal of the European Ceramic Society, v. 37, n. 4, p. 1847-1856, 2017. https://doi.org/10.1016/j.jeurceramsoc.2016.11.032

MEHTA, A.; SIDDIQUE, R.; Strength, permeability and micro-structural characteristics of low-calcium fly ash based geopolymers. Construction and Building Materials, v. 141 p. 325-334, 2017. https://doi.org/10.1016/j.conbuildmat.2017.03.031

MOR, S.; CHHODEN, K.; NEGI, P.; RAVINDRAC, K. Utilization of Nano-Alumina and Activated Charcoal for Phosphate Removal from Wastewater. Environmental Nanotechnology, Monitoring \& Management, v. 7, p. 15-23, 2017. http://dx.doi.org/doi:10.1016/j.enmm.2016.11.006

NEKHUNGUNI, P.; TAVENGWA, N.; TUTU, H. Investigation of As(V) removal from acid mine drainage by iron (hydr) oxide modified zeolite. Journal of Environmental Management, v. 197, p. 550-558, 2017. https://doi.org/10.1016/j.jenvman.2017.04.038

NIMICK, D.; GAMMONS, C.; PARKER, S. Diel biogeochemical processes and their effect on the aqueous chemistry of streams: A review. Chemical Geology, v. 283, p. 3-17, 2011. https://doi.org/10.1016/j.chemgeo.2010.08.017 
OJUMU, T.; PLESSIS, P.; PETRIK, L. Synthesis of zeolite A from coal fly ash using ultrasonic treatment - a replacement for fusion step. Ultrasonics Sonochemistry, v. 31, p. 342-349, 2016. http://dx.doi.org/10.1016/j.ultsonch.2016.01.016

OZBAYOĞLU, G.; EVREN ÖZBAYOĞLU, M. A new approach for the prediction of ash fusion temperatures: A case study using Turkish lignites. Fuel, v. 85, p. 545-552, 2006. https://doi.org/10.1016/j.fuel.2004.12.020

REHAN, M.; MIANDAD, R.; BARAKAT, A. M.; ISMAIL, I. M. I.; ALMEELBI, T.; GARDY, J. et al. Effect of zeolite catalysts on pyrolysis liquid oil. International $\begin{array}{lllllll}\text { Biodeterioration } \quad \text { \& } & \text { Biodegradation, } & \text { v. 119, p. 162-175, }\end{array}$ http://dx.doi.org/10.1016/j.ibiod.2016.11.015

SIMATE, G.; MALEDI, N.; OCHIENG, A.; NDLOVU, S.; ZHANG, J. L.; WALUBITA, Coalbased adsorbents for water and wastewater treatment. Journal of Environmental

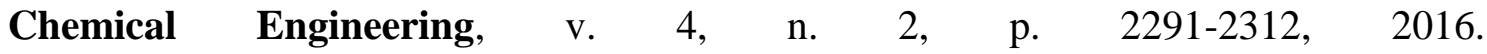
http://dx.doi.org/10.1016/j.jece.2016.03.051

SONG, W.; TANG, L.; ZHU, X.; WU, Y.; RONG, Y.; ZHU, Z. et al.Fusibility and flow properties of coal ash and slag. Fuel, v. 88, p. 297-304, 2009. https://dx.doi.org/10.1016/j.fuel.2008.09.015

TANG, J.; STEENARI, B. Solvent extraction separation of copper and zinc from MSWI fly ash Leachates. Waste Management, v. 44, p. 147-154, 2015. http://dx.doi.org/10.1016/j.wasman.2015.07.028

UNUMA, H.; TAKEDA, S.; TSURUE, T.; ITO, S.; SAYAMA, S. Studies of the fusibility of coal ash. Fuel, v. 65, p. 1505-1510, 1986. https://doi.org/10.1016/0016-2361(86)90325$\mathrm{X}$

VAN DYK, J. C.; BENSON, S. A.; LAUMB, M. L.; WAANDERS, B. Coal and coal ash characteristics to understand mineral transformations and slag formation. Fuel, v. 88, p. 1057-1563, 2009. https://dx.doi.org/10.1016/j.fuel.2008.11.034

VISA, M. Synthesis and characterization of new zeolite materials obtained from fly ash for heavy metals removal in advanced wastewater treatment. Powder Technology, v. 294, p. 338-347, 2016. http://dx.doi.org/10.1016/j.powtec.2016.02.019

WAN, C.; DING, S.; ZHANG, C.; TAN, X.; ZOU, W.; LIU, X. et al. Simultaneous recovery of nitrogen and phosphorus from sludge fermentation liquid by zeolite adsorption: mechanism and application, Separation and Purification Technology, v. 180, p. 1-12, 2017. http://dx.doi.org/10.1016/j.seppur.2017.02.031

WANG, C.; LI, J.; SUN, X.; WANG, L.; SUN, X. Evaluation of zeolites synthesized from fly ash as potential adsorbents for wastewater containing heavy metals. Journal of Environmental Sciences, v. 21, p. 127-136, 2009. https://doi.org/10.1016/S10010742(09)60022-X

WANG, S.; WU, H. Environmental-benign utilisation of fly ash as low-cost adsorbents. Journal of Hazardous Materials, v. 136, p. 482-501, 2006a. http://dx.doi.org/10.1016/j.jhazmat.2006.01.067

WANG, S.; ZHU, H.Z. Characterisation and environmental application of an Australian natural zeolite for basic dye removal from aqueous solution. Journal of Hazardous Materials, v.136, p. 946-952, 2006b. http://dx.doi.org/10.1016/j.jhazmat.2006.01.038 
WEBER, W. J.; MORRIS, J. C. Kinetics of adsorption on carbon from solution. Journal ofthe Sanitary Engineering Division, v. 89, p. 31-60, 1963.

YAO, Z. T.; JI, S. X.; SARKER, K. P.; TANG, J. H.; Ge, L. Q.; XIA, M. S.; Xi, Y.Q. A comprehensive review on the applications of coal fly ash. Earth-Science Reviews, v. 141, p. 105-121, 2015. https://doi.org/10.1016/j.earscirev.2014.11.016

ZHU, M.; JI, R.; LI, Z.; WANGA, H.; LIU, L.; ZHANG, Z. Preparation of glass ceramic foams for thermal insulation applications from coal fly ash and waste glass. Construction and Building Materials, v. 112, p. 2016. https://doi.org/10.1016/j.conbuildmat.2016.02.183 